\title{
一種の計算圖表に依ろ陽當りの圖表計算
}

通常會員小泉唒

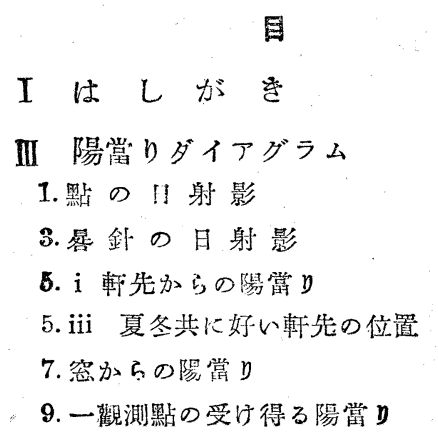

次

II 陽笛り曲絈圖表
2 崣直棒の日射影
4, 墀の日身影
5. ii 防暴的な軒先の位置
6. 道路と沿道の建物との陽當 $\eta$ 㯺你
8. 陽當りの邪魔物

IN む び

\section{I.は しがき}

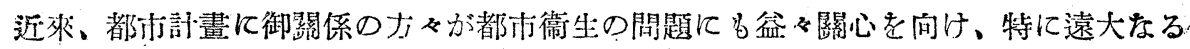
眼光を以て綠地の獲得と保存とに努力されて居る事は、都市生活者一一延いては國长全

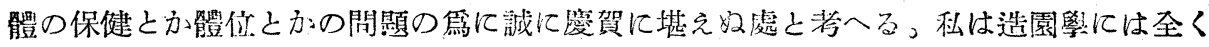

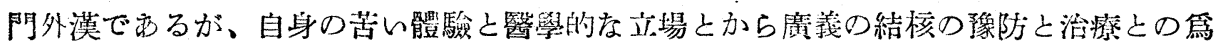

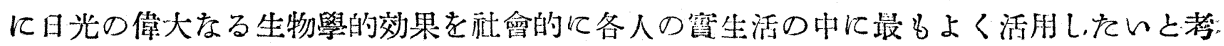
へて此研究考始めた。其結果、此問題の根本に觸れるには脩らしても都市䛅畫迄遡らな ければ成らぬ事を知つた。それで、本文には其處に到つた經過を記し、作せて日光の人

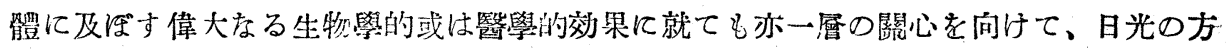
面でも結核に跱して都才計畫と醫學との共同戰線を一層緊密に張つて戴き度いと考へ、 敢て玆に筆を執る次第である。然し、日光の生物學的效果や文献に就ては原著照明學會 雜誌第甘答第三號記载の拙稿で補つて戴き度い。

\section{II. 陽當り曲線圖表}

計算圖表を筆ねて、陽當りを簡單に圖示する篇に、第一圖に示す通り私は先づ地本面 ヒの一定點 O（基點と名付けた）に $て$ 丈けの長さの重直溙POを立てた時、其尖端たる 頂點 P（支點之名付けた）の日射線P'が時間の經過と共に該地平面上に描く可き軦跡つ 
曲線（陽當り曲線 Insolation Curve と名付けた）を、例へば日本古來り歷法に在る甘

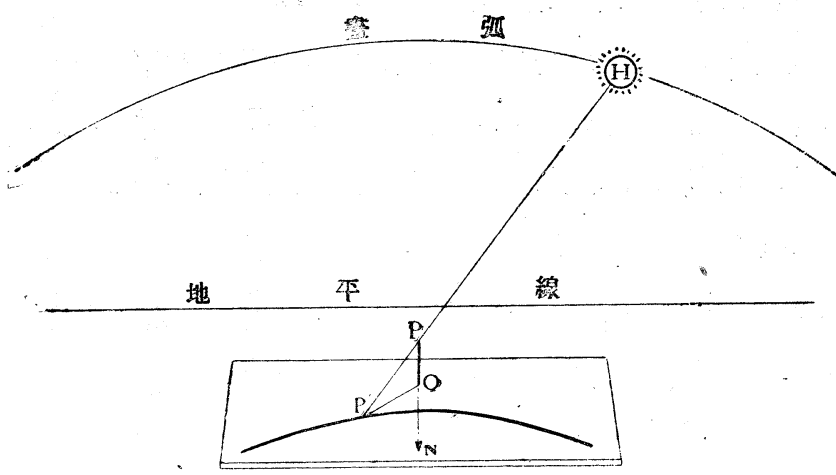

第一圖 陽，當 $D$ 曲 線

四氣笁の榜に。一管の 闍隔を持つを一年中つ 代表日に就て求め。是 を垂直棒の)接地䁿（些 點） $\mathrm{O}$ と共に一松の縕

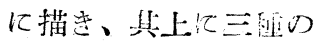
目塩を施した。 此目盛の第一は等時 線と名付け。水本型日 時棓の目盛老其儘採川

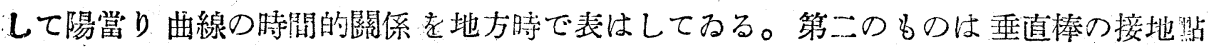
(基點) $\mathrm{O}$ を通る子午線 $\mathrm{NO}$ と、基點 $\mathrm{O}$ を中心とする放射狀の刻線（圖表の混雜を防ぐ䈍に

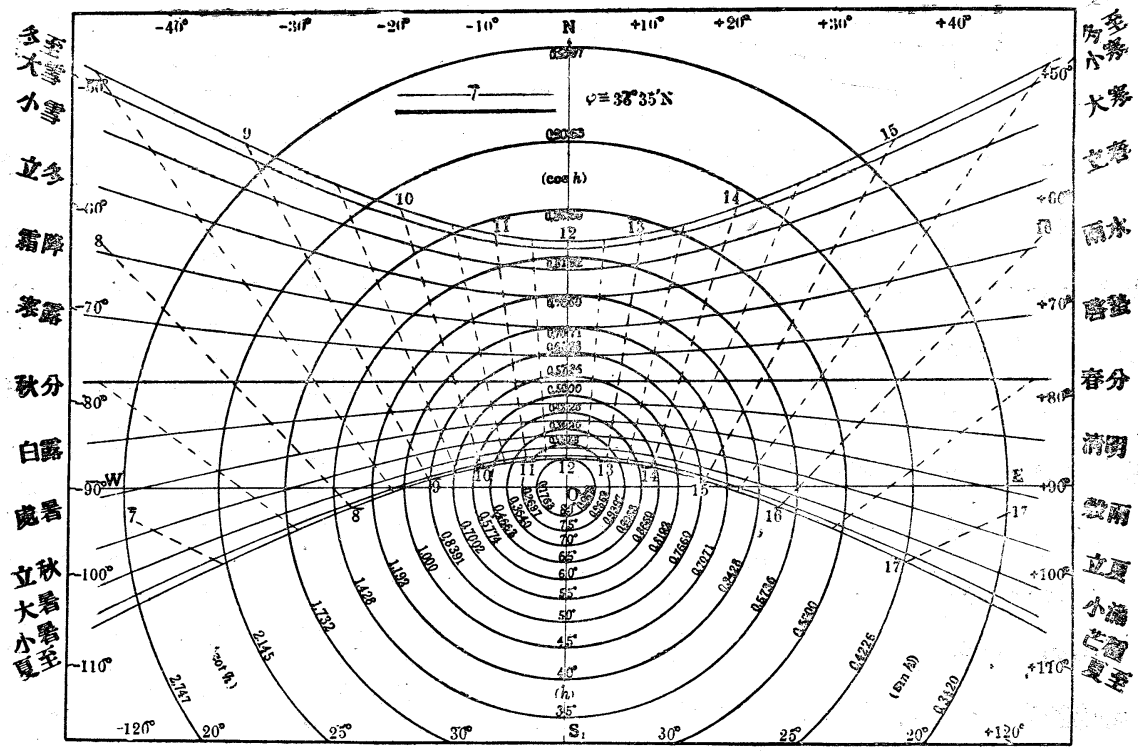

第二圖 連 續陽 䓨り曲線圖 表(福岡)

第二圖では体に沿うて其一部丈け描いた）とから成り、太陽つ方值手を指示する目盛で ある。第三の目盛は甚點 $\mathrm{O}$ を中心する同心圆の目盛であつて、等角線と名付村、太陽

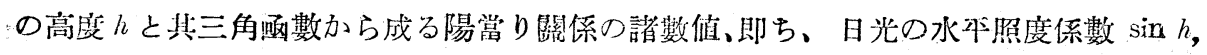
日光の鉛直線熙度係數 $\cos h$, 及び影長係數 $\operatorname{coth}$, 等を゙示すものである。 
そちすると、是厄低つて一地方一年間の陽當りを其日週期と年週期とを以て起る變化 をも含めて、或程度迄は量的にも質的にも表現する事が出來る。そして、任意の代表日 時に於ける陽當り關係の諸數值は其日時に對應する曲線上の一點P’に依つて種ぬの目盛 を讀めば直に分る、此樣な圖表を私は連續陽當り曲線圖表 Serial Insolagraph 或は簡單 て略して陽當り曲線圖表 Insolagraph と名付ける。（第二圖の陽賞り曲線圖表は紙面の 廣さの都合上、太陽高度 $h$ が約井度以下の部分は省略した)。

申す迄もなく、陽當り曲線は垂直棒POの長さ $l$ に依り相似的に、叉、觀測地點（主

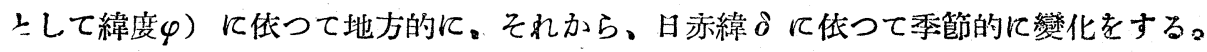

\section{III・陽学りダイアクラム}

次に述べる㥞に、陽當り曲線圖表を用ひて、例へば、空とか椖とかに就て、其一年中 の陽當り或は日射影の變化を表はすダイアグラムを私は陽虽りダイアグラム Insolation Diagram と名付けた。今、二三の簡骂な閣題に關するもの者代表的に述べて見上5。複 释な問題は簡單な問題を部分品として幾つか組合せたものに過ざをいと思ふ。

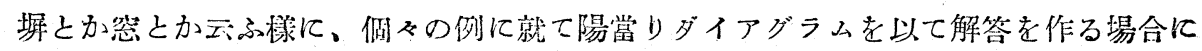
は、先づ、䦌趋の對象物の縮小模型を作つて其縮尺を丁度問題の中心點例へば、潫に於 ては其垂直なる一邊が、丁度、陽當り曲線誾表の垂直棒の長さ $l$ に等しくなる樣にして 是を圖表の上に、問題の中心點が其垂直溙と一致し、且つ方位も正しく咀かれたるのと して考へ始めなければなら权。それで、記述の煩を省くために、以上の手續をする事を

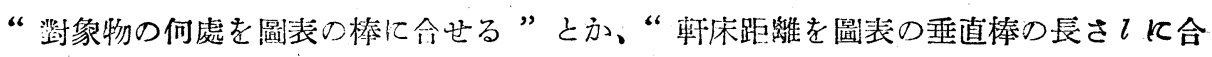
せる”と云ふ風に簡紧に記截する事に約束をさせて頂き度い。

\section{1. 點の日射影、と}

\section{2. 垂直捧の日射影}

陽當り曲線疃表は其睢で此兩者の陽當りダイアグラムである事は申すまでもない（第 二圖)。

其處で、今、垂直棒を以て樹术を代表せしむる時は、此ダィアグラムに任つて夏の日

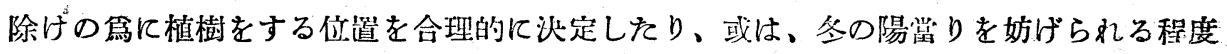
を豫知して、其對策を講したりするのに役立つたらら。

\section{3. 㛑針の日射影}

地平面上に傾斜して立つ棒つ代表として水平型日時計の暴邻 Gnomon を摆び、其日

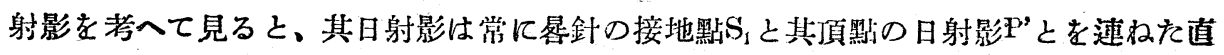


線である。それで、陽當り曲線圖表上に於て、昆針の頂點を支點 $\mathrm{P}$ 亿合せ、㟯針の仰角と 方位角とに依り其接地點 $\mathrm{S}_{1}$ を求めて置けば、此圖表から任意の日時に於ける崇針の日射 影を容易に求め得るから、是を暑針の陽當りダイアグラムとする事が出來る(第二圖)。

此陽當りダイアグラムから出發して、垂标の陽當りダイアグラムは容易に作る事が出 來る。

\section{4. 塀の日射影}

第三圖の樣に、榐を箭や壁面の樣な地平面に垂直に立つ矩形本面の代裴奨として、其

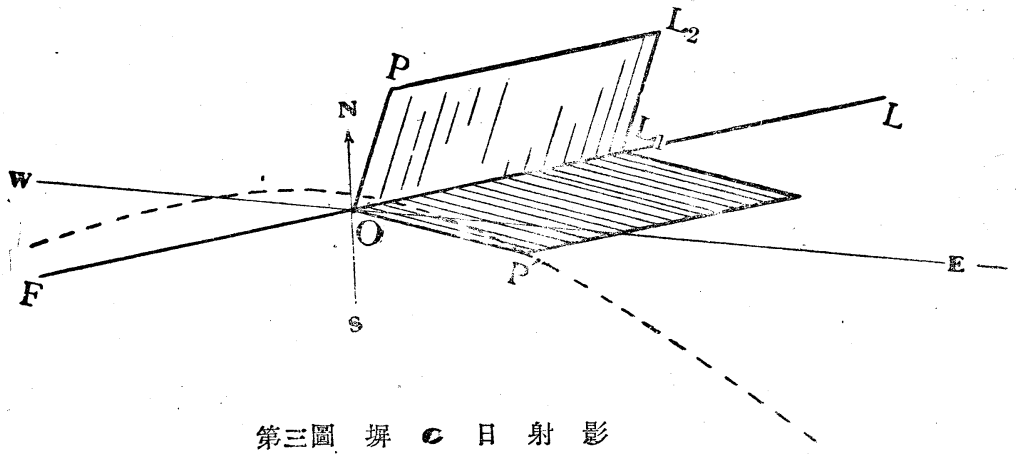

地平面上の日射影を考へて見ると、それは常に其一邊を成す垂直線 $\mathrm{PO}$ の射影 $\mathrm{P}^{\prime} \mathrm{O}$ 上 塀の接地線 $\mathrm{OL}_{1}$ とで決定される本行匹邊形でるるから、堀の垂直なる一邉 $\mathrm{P}^{\prime} \mathrm{O}$ を圖表つ

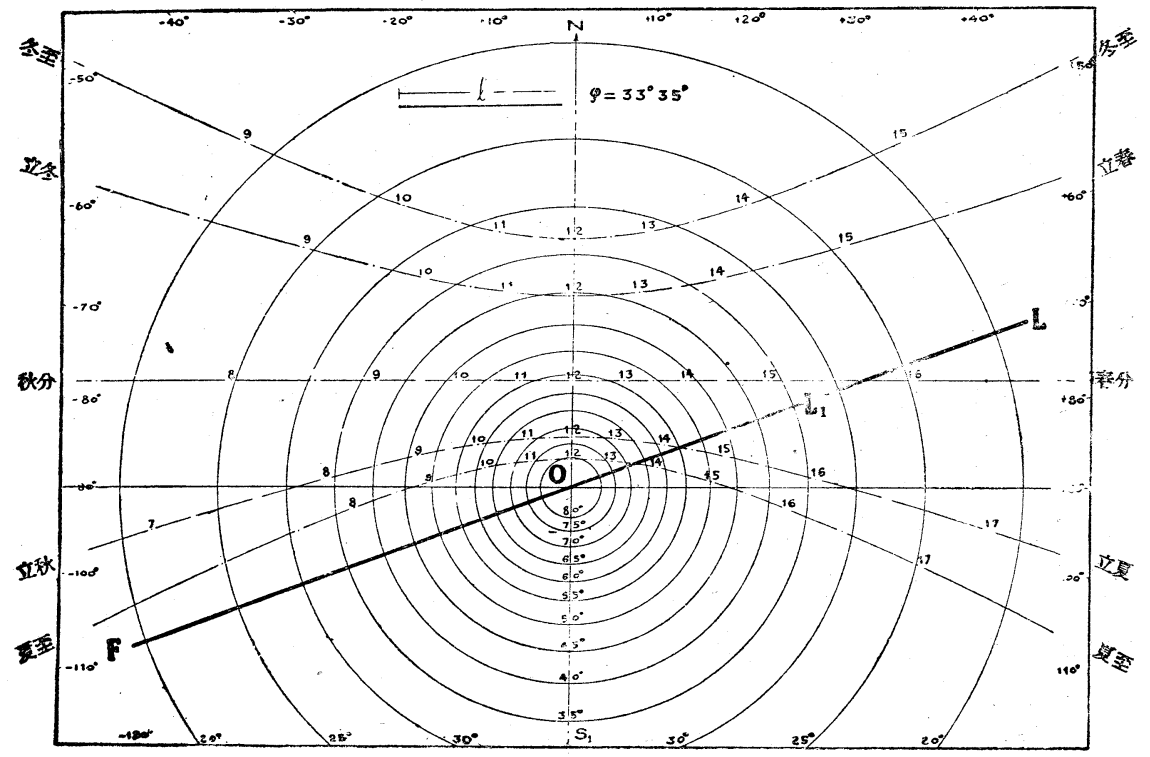

第四圆 塀（地本面に立つ昰㨁矩形本面）の陽當リダイアグラム 


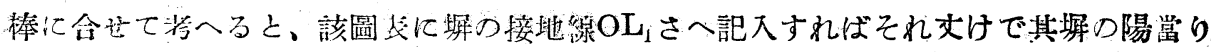
ダイアグラムとする事が出夾る 第四圆)。

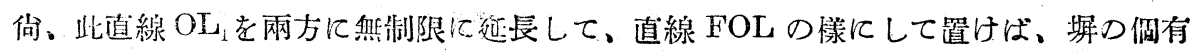

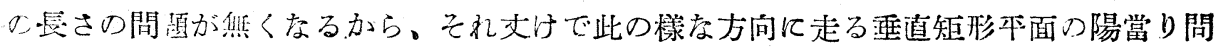
題の公式の樣なダイアグラムになる。そして、此の直線 FOL に依つて圖斐は二分野に 分割され。各分野丙に在る陽當り曲線が塀の夫ネり側に於ける一年中の日射影を表はし ○るる。

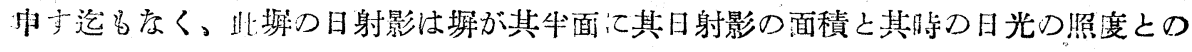

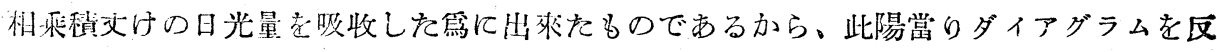

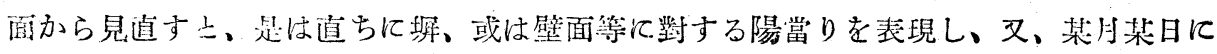

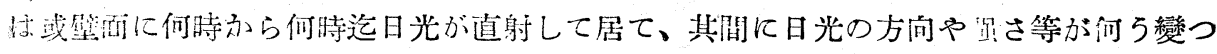

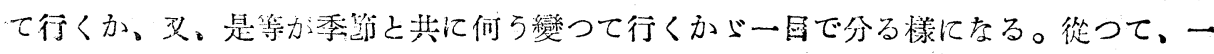

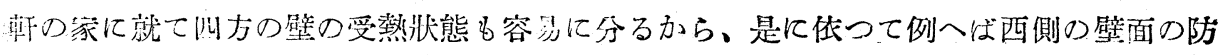

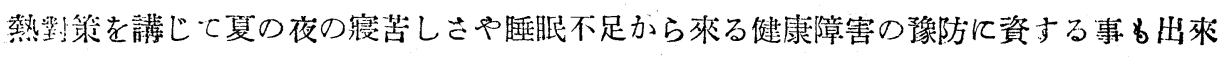
る。

此䚄の陽當りダイアグラムは次に述べる通り少し手を加へて展開すると種ふの閜題つ 陽當りダイアグラムが出來る。

\section{5. i 亁珗からの陽當り}

茲には先つ軒先丈けを閣題とし、其兩端つ傍垂木の下から這大る直的日光さ除外して

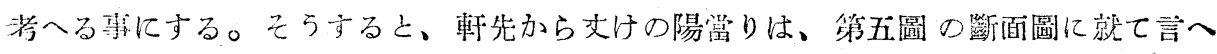

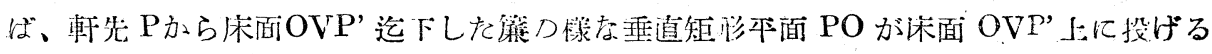

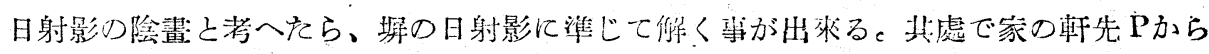

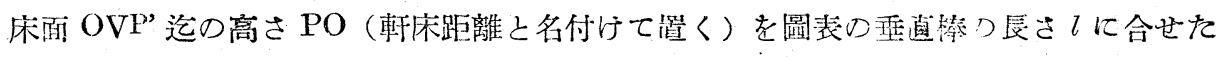

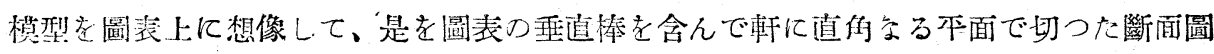

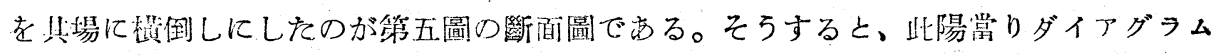

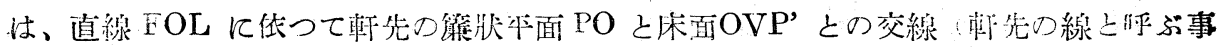

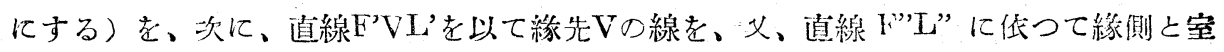
內との境界線を意味せしめて、圖表面を室內、緣側、軒下及び庭園老意味する分野に分 割せしめたら州來上る。そして、各分野內取込まれた陽学り曲線がー年間に各分野内 に落ちる軒先の日射影 曲線!:の一點を通り直線 FOL に平行な線で現はれる)の存在 と其變化とを示すから、例へば第五團の例では、春秋分には日出時から午前十一洔近く 166 


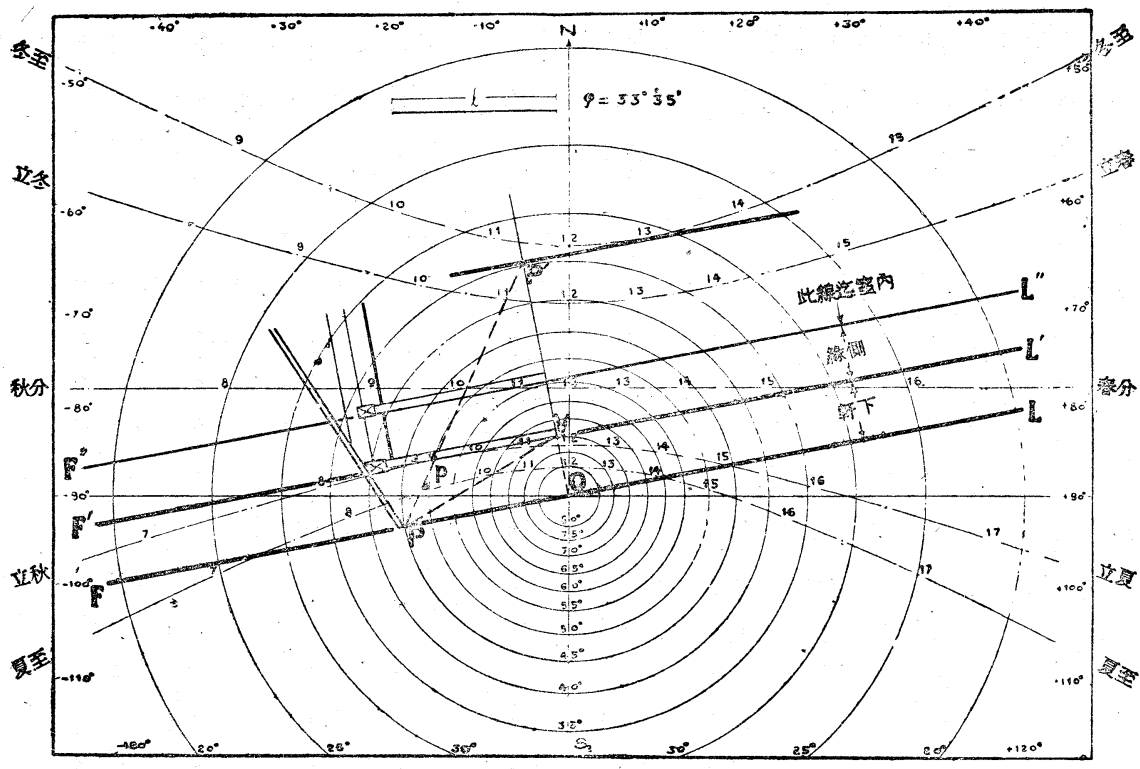

第五圖斬先の陽當り多ダイノグラム

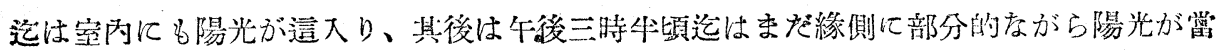
つて居る事が直ち反分る。

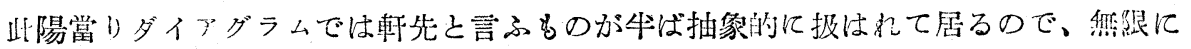
長い軒先こして表現されて居る。然し、もつと委しい事が必要孛らば、岰面圖の床下の

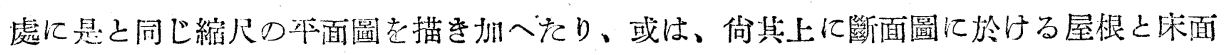
。と老表はす二線つ交點に低つて垂木の延長の接地點を求め、垂木と軒先との日射影の決

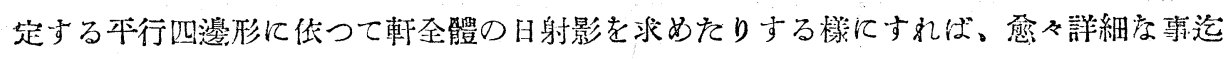
分つて來る。

\section{5. ii 防暑的な軒先の优置}

今度は既成家屋ではなく、上訅の家の設計の際に、“立夏から立秋迄つ一香暑い夏つ 烈日が、傍垂术の下から來るの丈けは我慢するが、軒先からは這大ら炇㥞にして吳れ” と註文されたとすると、早速陽虽り曲線圖表（第五圖）の基點 Oを通り軒先の線 FOL を引き、炏に、此直線 $\mathrm{FOL} に$ 平行にして、且つ、立夏立秋の陽當り曲線に切与る直線

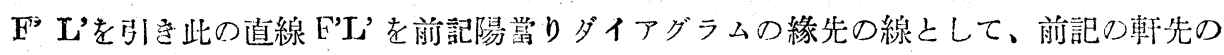
陽虽りダイアグラム製作とは反對の順序で設計を進めたら好い。即ち、( $\mathrm{PO}=l)$ として 直出三片形 POVを作り、PO 軒床距離、OVを野出とするのでする。そうすると、斷 
面圖に於て、軒先を本面 PV 上に持つて來れば好い事が分る。然し、若し前記の柡な二

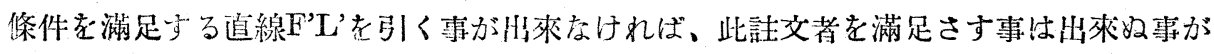
分るが、それでも、佮、此圖表㹥其埸合の最善鉴策の樹立には充分役立つから、是に依 つて夏の健康障害を毁減し、且つ健康增進に資する事が出來る。

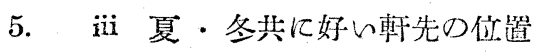

以上の考へをるら一つ擴げて軒先の在る可を位置を定めたら、上訅の樣に夏は充分防 暑つ役に立ち、同時に、冬は、例へ多至の頃には、軒先が室先の陽當りを邪魔しない 樣にも出來る。其方法は、先づ、防暑的な軒先を求める第の直角三角形 POV 求め、 次に、直線 FOL に本行して同時に冬至の陽虽り曲線沉切する直線を引き。直線 OV D 趠長との交點をP'とする。そして、P とP’ とを結び、直線 $\mathrm{F}^{\prime} \mathrm{L}^{\prime}$ との交點を $\mathrm{p}$ とす。そ 万すると、通線 $\mathrm{PO}$ と直線 $\mathrm{OV}$ と直線 $O \mathrm{P}^{\prime}$ と直線 Vp との四者の關係は斷面圖ででも分 る通り、軒床距離と靪出と床面之网戸の高さとの關䋆になり、叉、軒先が平面 PV 上に 在れば立夏から立秋迄の間は軒先から来る直射日光を防げるし、同樣にして、軒先が平 面P P'上に在れば冬至の頃には此家（室）国有の陽當りを妨げられはしない。從つて、

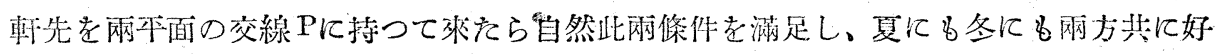
几軒先の位置を求的る事が出來る。上拈の作圖で、直線FOL 几對する第二の平行線を

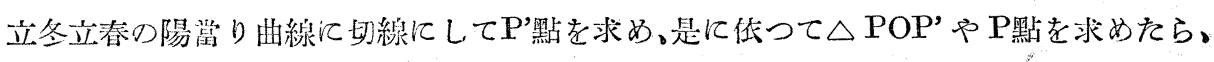
夏は前記の䡬で、冬の方は立冬から立春迄陽光を䐽契する事が出來る稼になる。

此樣にして、軒先の位䏣を合理的に決定すれば、夏は健康障害を防を、同時に冬は不

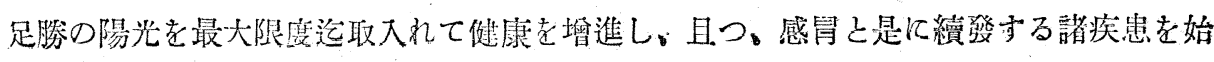
め、種ふの病氣の豫防澬する事が出來る。

然し、此樣に結構な軒先の仕置を求め得る䉆には、軒先の線 FOL の走る方向に一定の 限度があるし、又、此限度內に於ては或範圍を越したら市販の材木の寸法とか、建物の 外見とか種ふの技術上の問題等から事實上は家が茟て惡くなる。それで都市計畫つ際に は豫め建築家の協力子求めて此邊の事迄も充分若慮の內に入れられる事は最も骍ましい と落へる。

\section{6. 道路と沿道の建物との陽當リ關係}

今拍子木の稳に大さ相等しく、且つ、長い直方體二本て空り繪を描き、是を沿道の建 物と假想して地本面上に本行に並へ、淇間を道路之假定した模型に就て道路と沿道の建 物との陽當り關係を考へて見る之（第六圖）、是も亦、一側の建物の前壁面 $\mathrm{PO}$ が路面 $\mathrm{O}$ $\mathrm{V}$ と對側の建物又は其敷地とに落す日射影の問題（二悯の組合せ）と成る。そして、是 168 


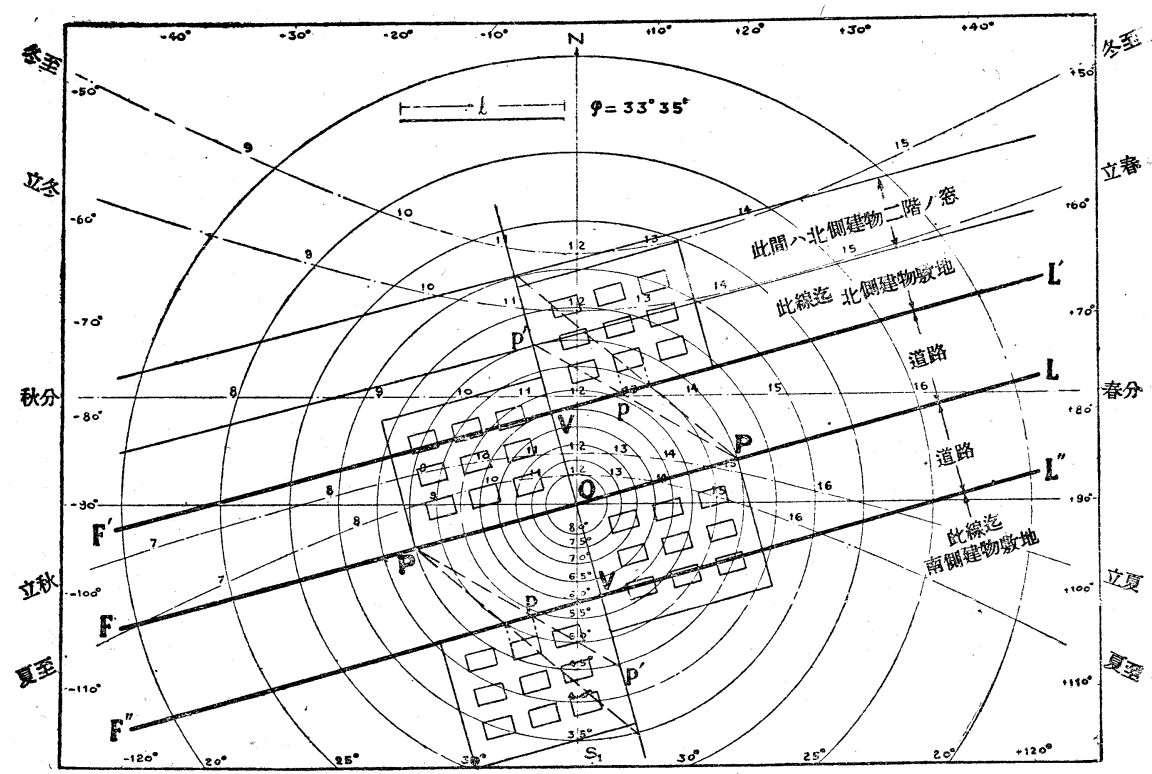

䈍六圖 道路と沿道の䞨物さの陽當りダイアグラム

を第五圖の軒先の場合と比べて見ると、軒先の箖沜平面PO は建物の前壁面と、又軒下

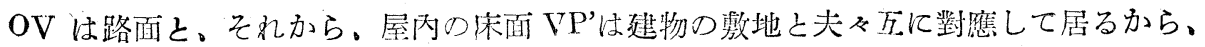

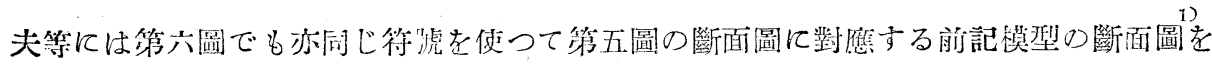
$(\mathrm{PO}=l)$ の割合で二つ描き、以て沿道兩側の建物の前壁面が夫ね投影側に立つ二つの場

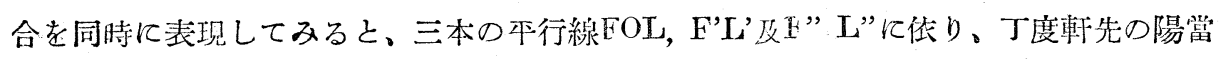
クダイアグラムを二つ会中合せに組合せた樣なダイアグラムが出來る(第六圖)。そし て、此三本行線の间之其兩側とに分れた分野が、夫心、路面之夫ょの側の建物の敷地之 を意味するから軒先のダイアグラムに準じて曲線在䜖めば奶い譯である。

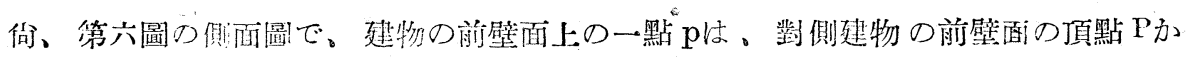

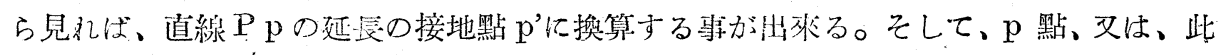
前壁面上で $\mathrm{p}$ 點と同じ高さの點は、此陽當りダイアグラムの上では、直線 $\mathrm{P}$ p’の仰角を

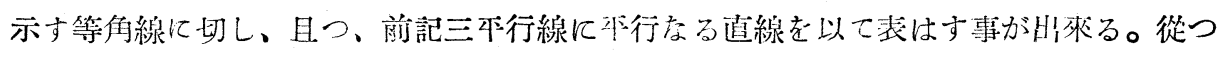

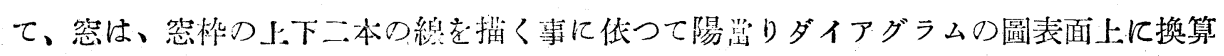
して表現する事が出來る。

1）此路面圖には說明の便宜上空を迫加してあるから、唇い棟の側面圖の樣に見 元了为知九如。 
此樣な陽嫦りダイアグラムは、市街地趣築物法や都方計畫に於て、道路の走る方向と

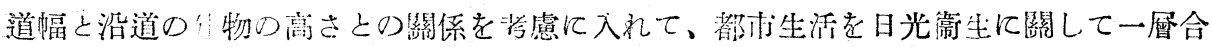

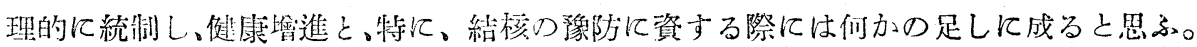

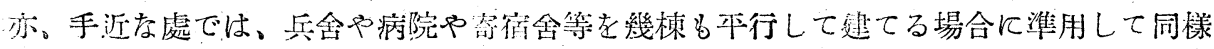
の效赑老舉げる呇も出來ると考へる。

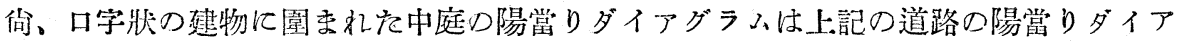
グラム老云つ十文字に組合せて、田字肤の分野を作つたらそれで出來る事は申寸迄もな wo

\section{7. 侧 空（空からの陽當り）}

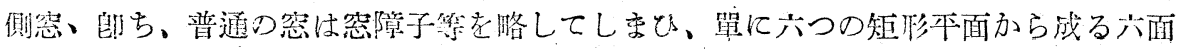

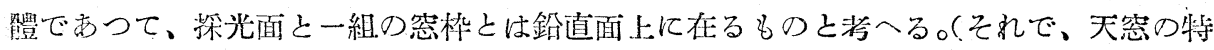
别の埸合である)。今、陽當りダイアグラムを作る営に、此空の外側採光面の一邊を陽當

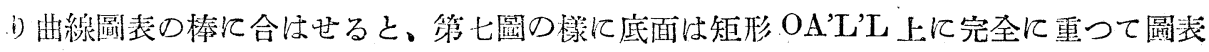

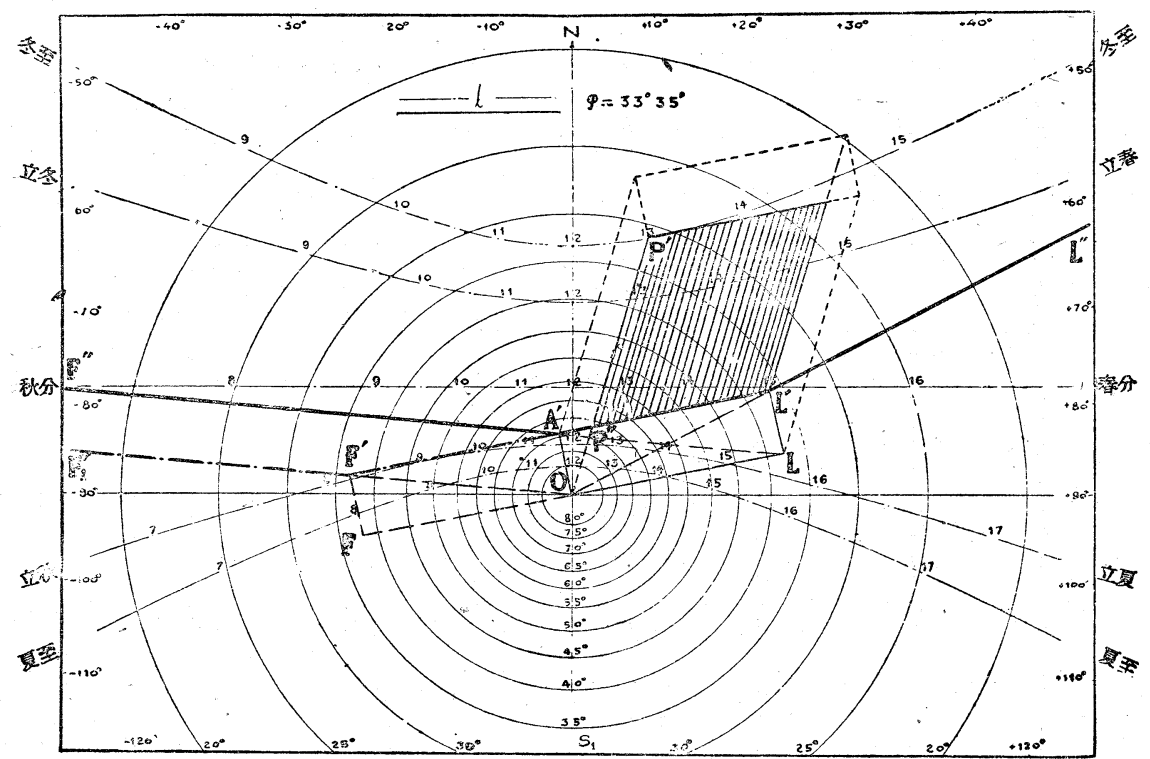

第七圖，側空の防當りダ、イアグラム

面上に現はれる。そして、此漾を窓から入射し得る直射日光の最大勢力籍圍を圖表面上

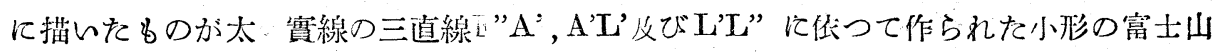
形の部分であつて、此䆒の陽當りダイアガラムとして陽當りを表現する分䟥は三限界直 線 $\mathrm{F}_{1}{ }^{\prime} \mathrm{F}^{\prime}, \mathrm{F}{ }^{\prime} \mathrm{L}$ 及び L’L”が作る大形の富士山である。そして、任意の特定日時（此圖で 


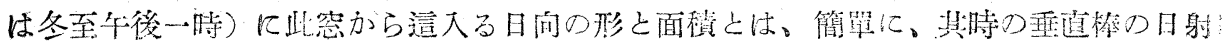

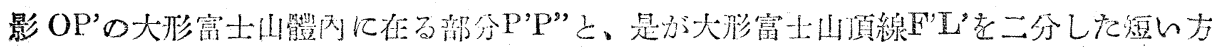

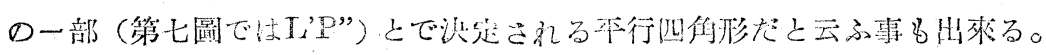

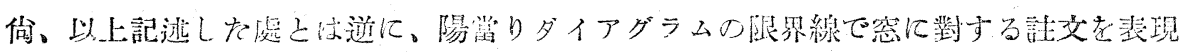

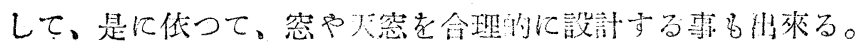

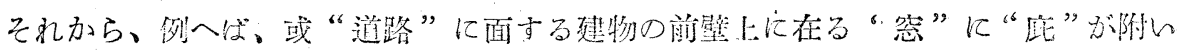

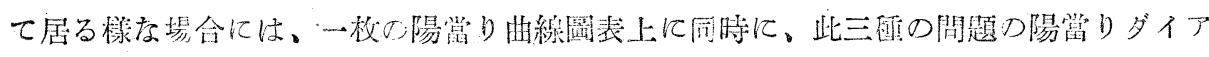

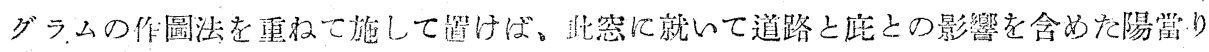
ダイアグラムが出來る。

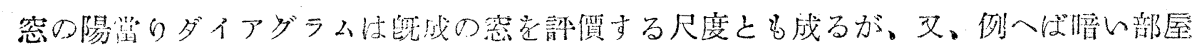

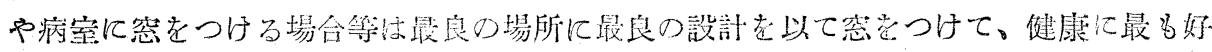

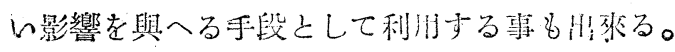

\section{8. 陽當りの邪覤物}

日光は本行光線であるから、水平度る本面上に在る平面圖形の日的影は原圖形が其儘

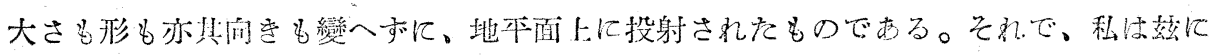

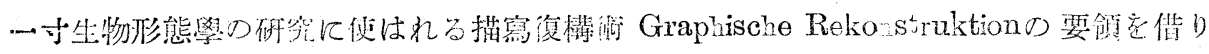

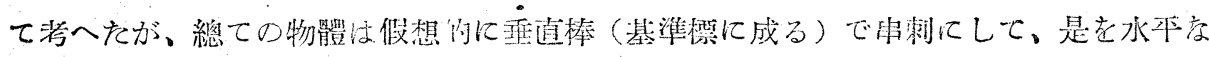

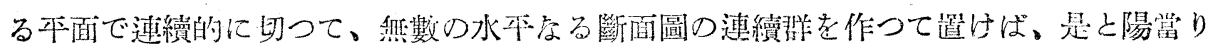
曲線圖表とに佧つて、其物體の任意の日時に於ける日射影を描畫的に合成する事が出來

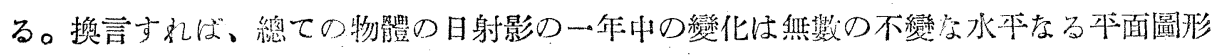
の連續群と垂直棒の日射影の變化とに分解する事が出來る。（無諭、是隹陽當りの開题 を考へる時の常識で市る。

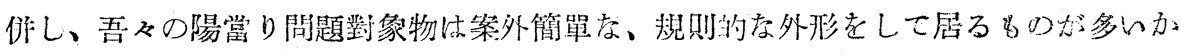
ら、其儘、又は、多少模型化すれで、もつと簡單に双扱へるものが多い。例へば符八圖 の家の日射影の中では、常に、大棟と軒先と天北と建物周圍の接地線との水本孛万平面 圖形が主役を勤めて居て、此家全體の日射影は、常に、上記の各主姴本面圖形の日射影 を適當に直線で連ねる事に低つて求める事が出本る。(第八圖では一例として冬至午後

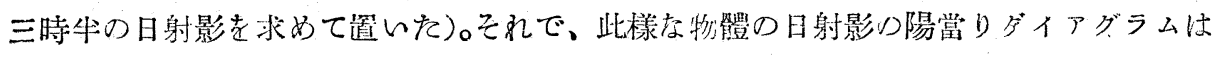

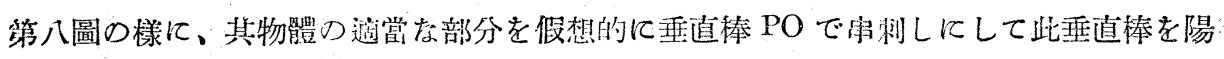
當り曲線圖表の垂直棒に合出て考へて、側面圖と平面圖とに作つて、第八圖の樣に、各

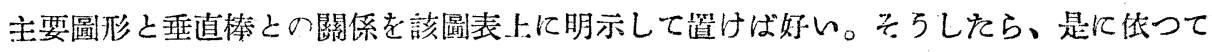




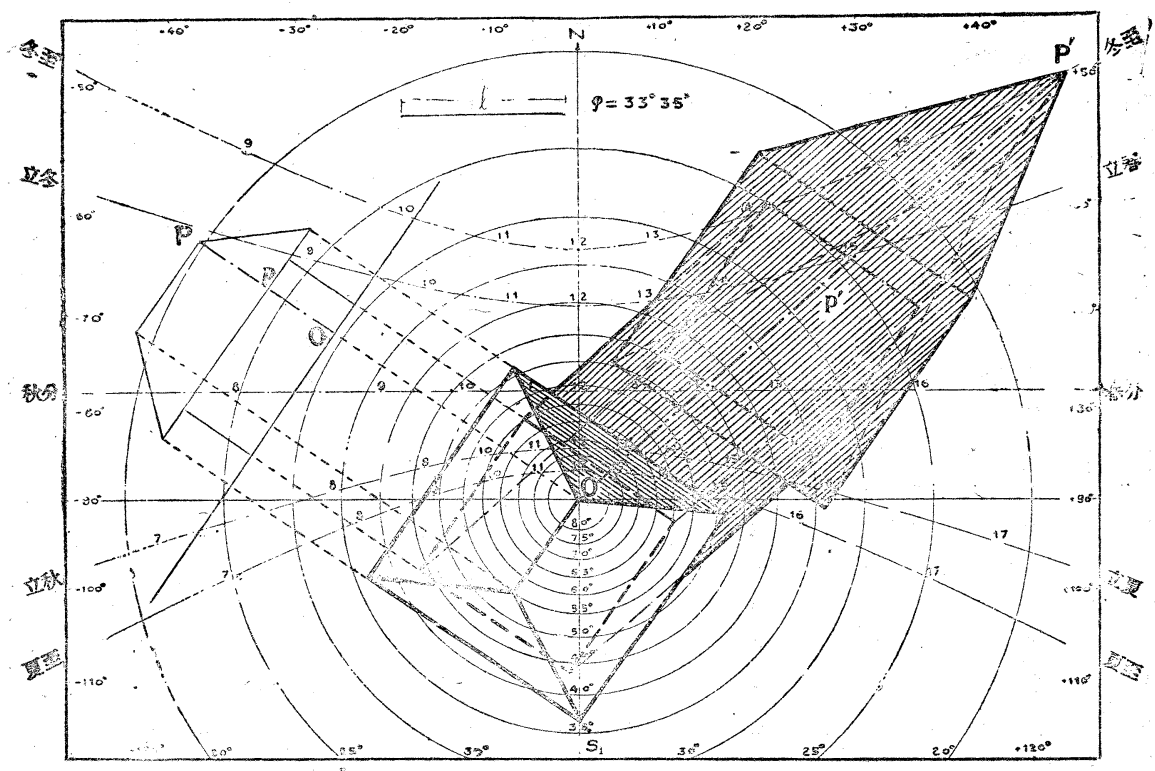

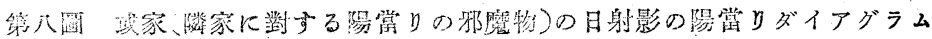

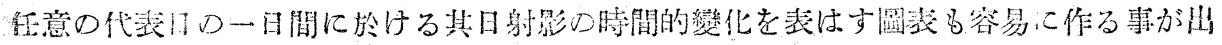
柬る。

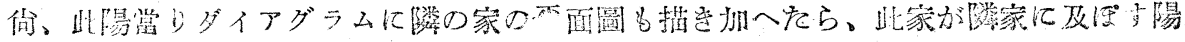

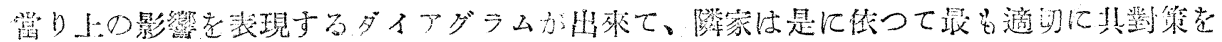

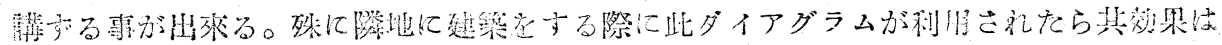

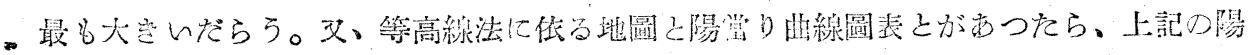

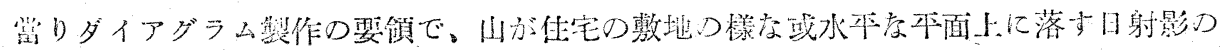

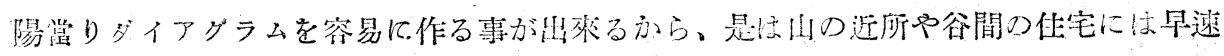
役に立つ。

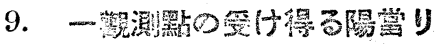

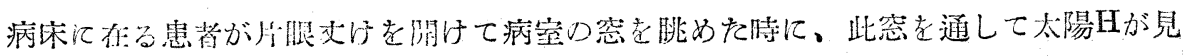

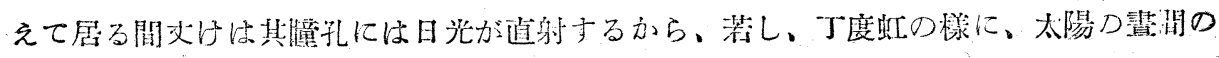

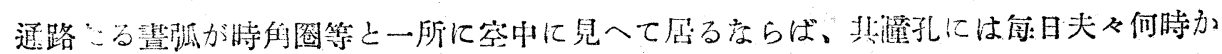

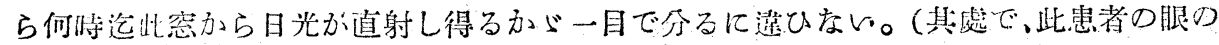

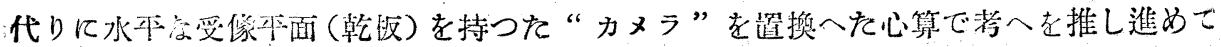
見小弓⿱。 


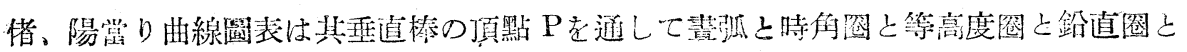
を水本なる本面トに投射したものである。それで。此圖至面を此投射の眝と同じ條件に

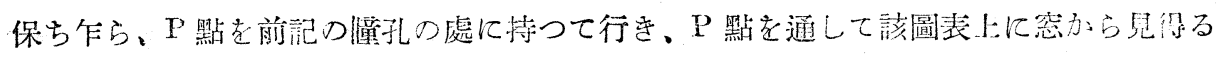
可視天空の投射像を投射し・陽虽りダイアグラムを作つたら、此可视天空投射像內に含

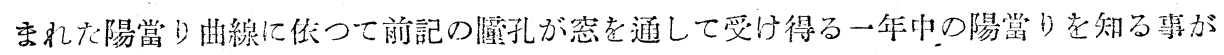

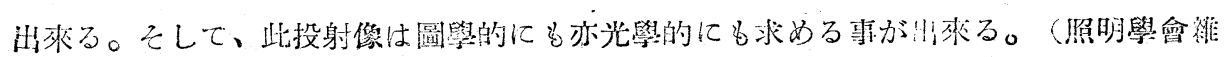

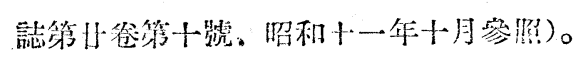

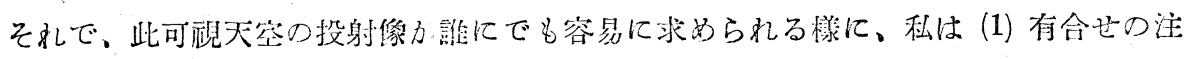
射藥の空箱つ一・側壁にピンホールを西けて其底面老受像面上した“ビンホールカメラ”

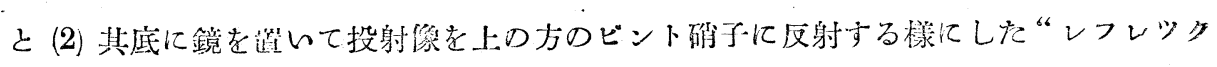
スカメラ”とを自作して（狄い意唥で“陽嫦りカメラ”之呼んで）使つて居る。

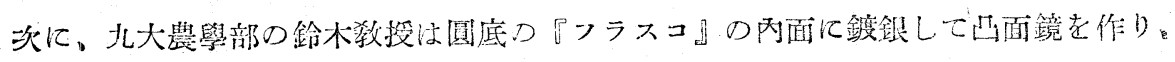

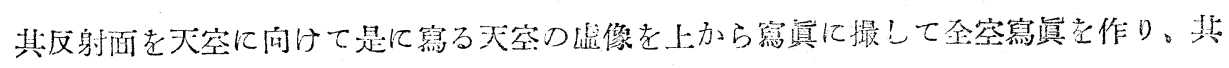

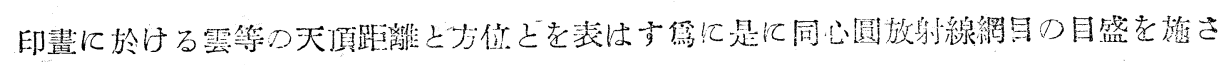

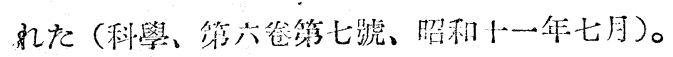

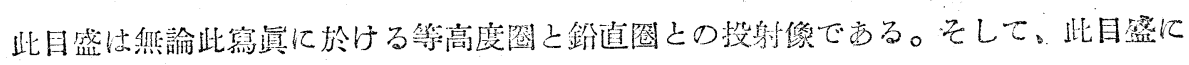

管光 圖

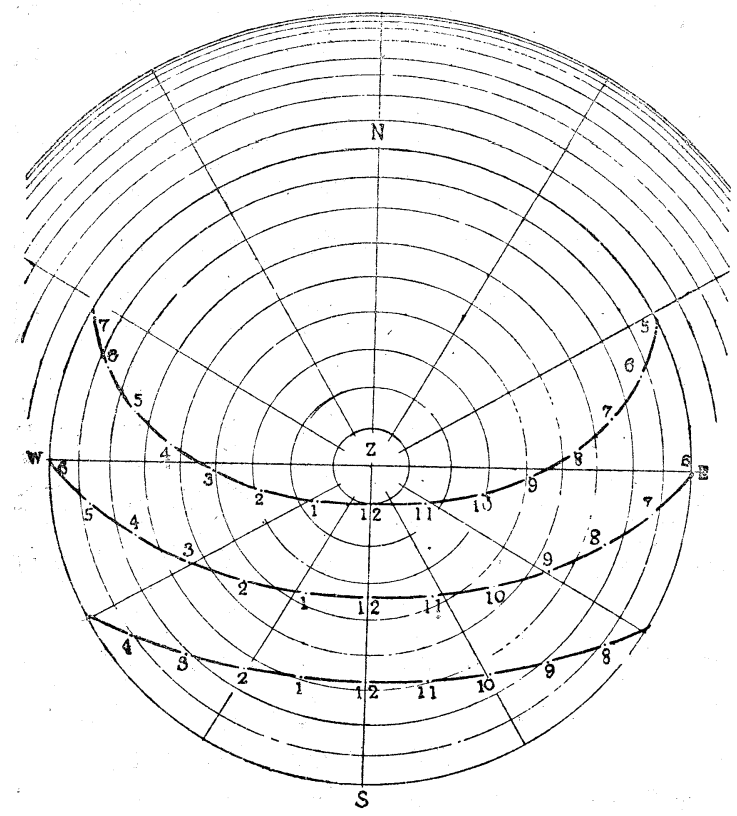

依つて一日中の备時刻に於ける 太陽刀值置記大してら。此目

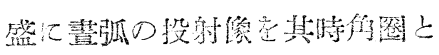

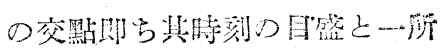

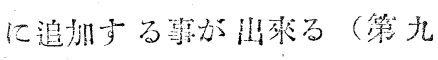

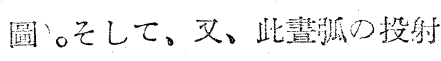

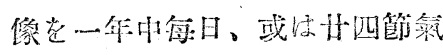

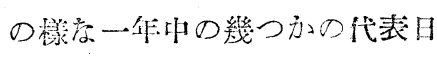
几就て求めて塩けば、丁度前記 の陽當り湖線圖表を此全空笉這 に適する稳に變形したものが得 られるから、此全空寫傎機密“陽 當りカメラ”之同樣に利用して 前記の『フラスコ』の中心て當 る一點の陽當りを覞測する事が 


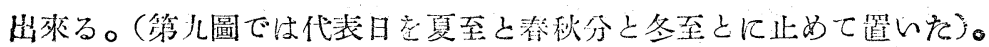

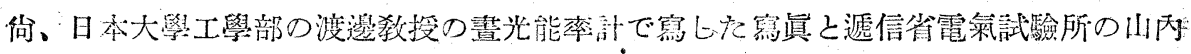

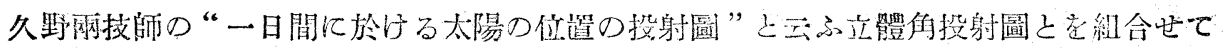

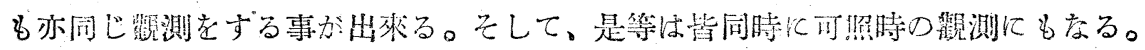

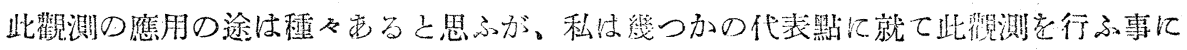

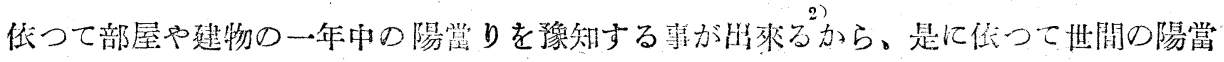

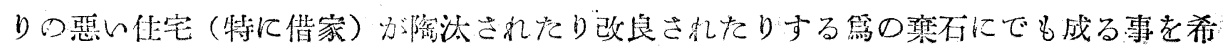
つて居る。

無論。庭園其他の植裁計墨の㭙に为利用が贷來ると思ふ。

\section{IV.むすび}

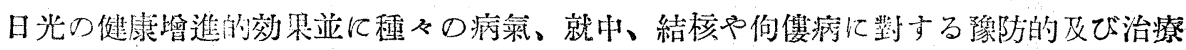
的频果の偉大さは大昔から一般の常識であると共に、近代科學に依つても是を實䇺され

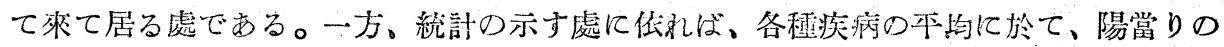
惡心家の群は陽省りの好い家の群に於りるよりは約三倍の篗病率を示すと考へられて居 る。そうすると、是丈けでも、任宅の陽當りの間題は豫防醫學や社會衞生の比らもつ 一とるつと重要視されても好い筈である。然し、今日迄醫學の烟沉は日光の生物學的效果

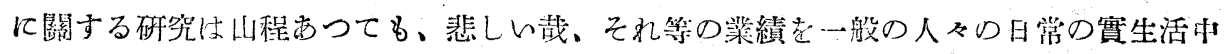
に十分活用さすのに必要な陽當りに紗する知識は誠に之しくて、一般には未だ畑違ひの

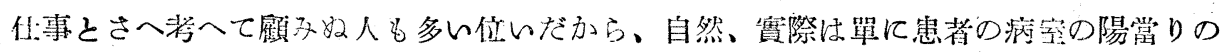

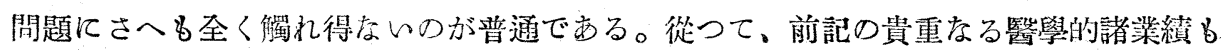

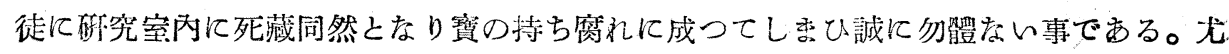
も、是は醫學が著しく治療䠓學の方にのみ偏して發澾した今日の現狀では或程度迄は恕 せられなければ致し方が無い事とは思ふ。

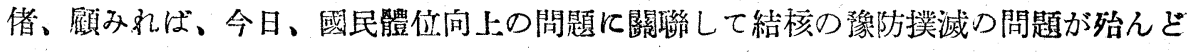
其の同意語同然のものとして我國の指導者達て依つて買劍に考へられて來たが、正直な

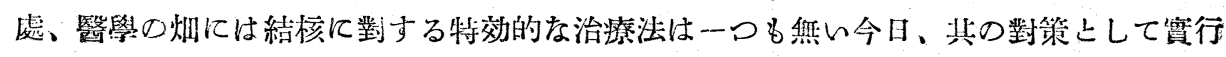

2）筆者の闰僚諸君も近頃は借家を探す特には“陽賞りカメラ”で此觀測を行ひ、是に 依つて冬の陽光に惠まれなかつたり或は夏は烈日がカンカン這入つて來たりする栐 な（私は此兩者何れも陽當りが惡いと云ふ）家は避けて借りぬ樣にして居る。 倨、此觀測に使ふカメラは昭和 3 年3月18日刀特許公報に公告されて居る。 
されよ5とする處は、今私の知る處では精々㳳成患者に對し所謂早期診斷を下し、不十

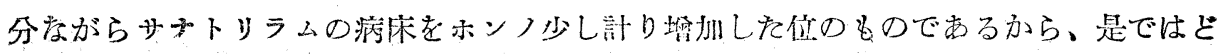

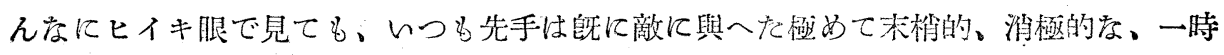

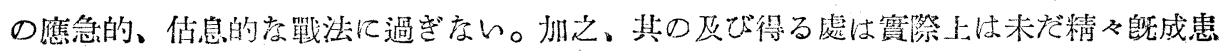

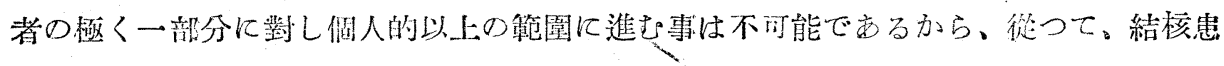

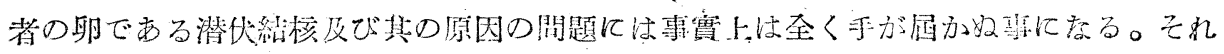

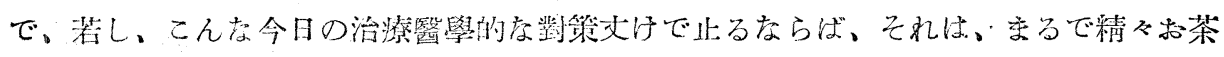

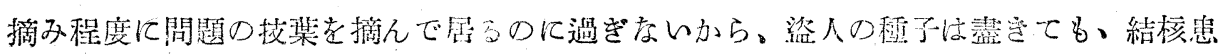

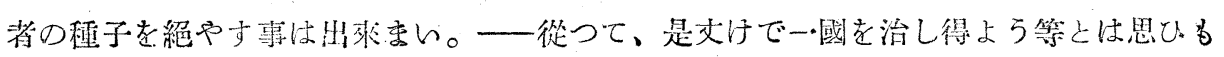
寄らぬ事であらうと思ふ。

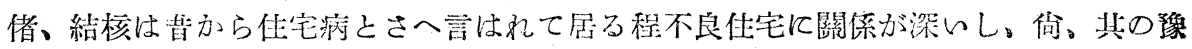

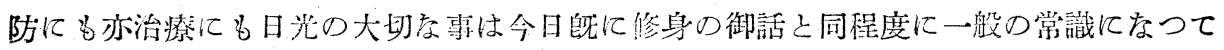

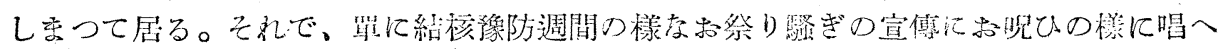

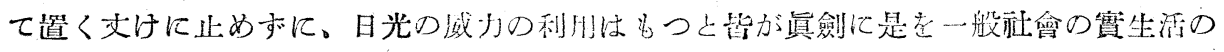

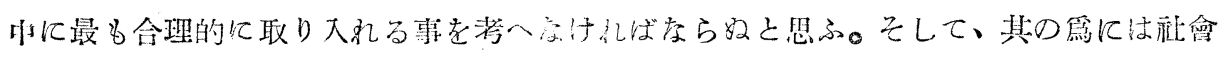
一般の住宅の陽當りと云ふ事が涅題に成る。

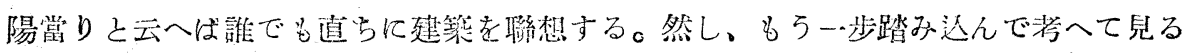
と、都市に於ては道路の走る方向は沿道の建物に對し、其の陽㖹りに閣しては其の大勢 を沃定的に支配する(そして、建築家つ舀し得る處は精々其の與へられた教地に延てる

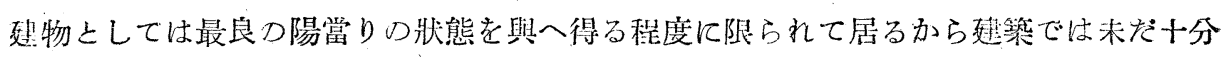
問超の根本几迄は觸れられね）事は営識でよ゙も分るが、私は本交沉於て迹べを圖表計算 に伭つて是を確證する事も出來ると思方し、义、此の圖表計算を逆朋して、豫め都市を 日光衛生的に最名合理的に計畫し、此の行政的手段に低つて永久に其の市印全體の日常 生活走日光衙生的に合理的に統制支配する事さへも出來る事在ハットリ知つた。乙して

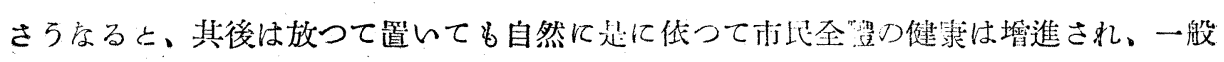

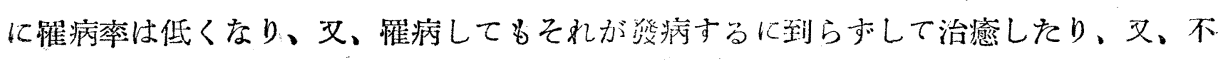

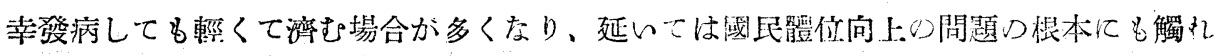
得る事は日光に關する醫學的生物學的諸澲績に依つて自ら䏛である。これで、日光の問

3）第五圆乃至第七圖之第四圖との陽當りダイアグラムを比較して見て載けば、建州の 外壁 (垂直壁) に當る直射日光が軒先や對側家屋や忿に依つてどんな制限を受けて 室內に大射するから゙分る。そして、此建物の外壁つ向く方向は都市計畫が交配する。 


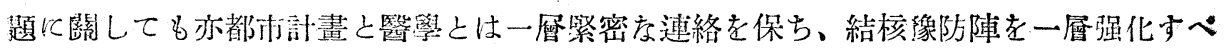

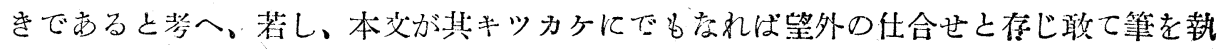
つ充次第である。(昭和13年1月 日本造園學會熦演)

（追記）御詐索願ひ、私はも5一度法に述べさせて戴委度い。

今、一般の都市の建物に臤入れられて居方遭射日光に就て侾へて見ると、私共は建物

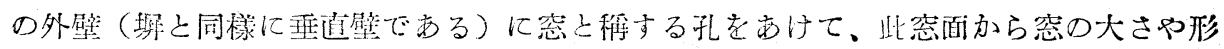

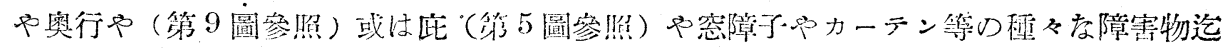

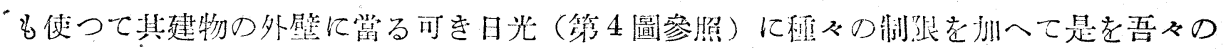
日常生活》川に取入れて居る。

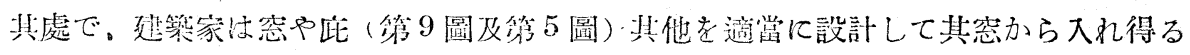

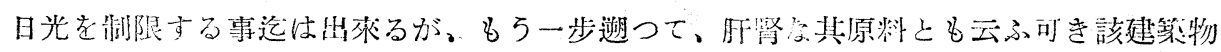

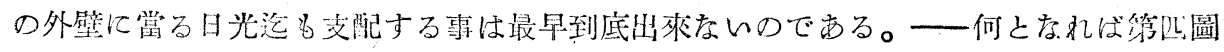

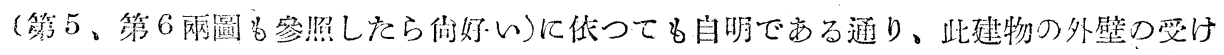
得る日光讷其外壁面の向いて居る力向によつて決定されるが。此外壁の向く方向は普通 は道路の走る方向によつて苂配されて居るからである。

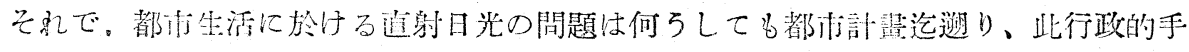

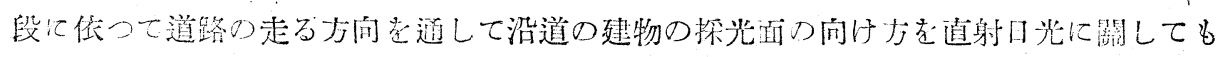

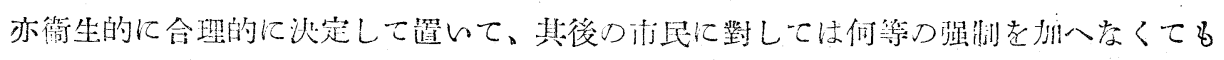
不殱の間に自然に日光が最も合理的に配給される様に統制しなければ徹底物に解決が出

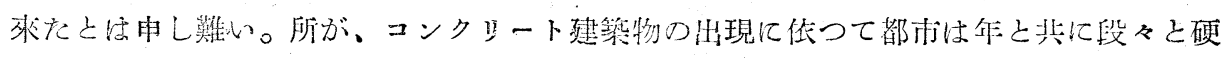

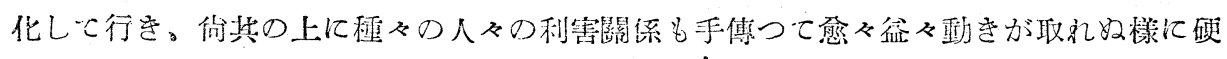

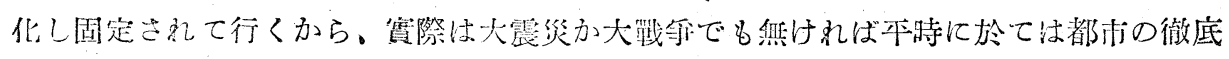

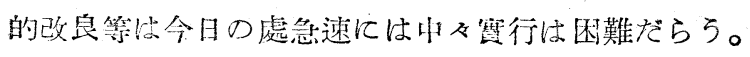

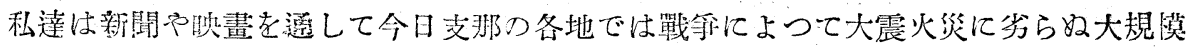
な都市の徹底的破壞が行はれ居る事を見せつけられて居るが、私は此の徹底的破壞こそ

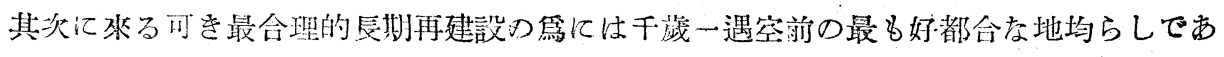
れと柝つて居る。そして、私は都术計畫者も含めて日本の指導者達が日滿支各地で都市 の改良や越設や再连設在計畫する際には廣く工學や醫學や其他各方面之る協力して總て の知識を集めて此入間の健沓を支配する日光の問題に對しても特に正倠な數量的豫測を

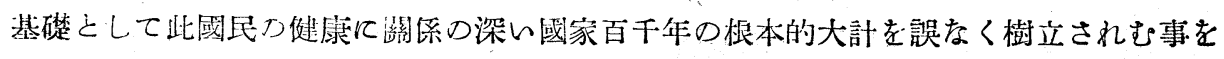
䨩心から期待する炏第である。 